\title{
PENERAPAN TOTAL QUALITY MANAGEMENT PADA PROGRAM STUDI MPI FAKULTAS TARBIYAH DAN KEGURUAN UIN ALAUDDIN
}

\author{
Syahid \\ Fakultas Tarbiyah dan Keguruan UIN Alauddin Makassar \\ Kampus II: Jalan Sultan Alauddin Nomor 36 Samata-Gowa \\ Email: syahid.6868@gmail.com
}

\begin{abstract}
Abstrak:
Tujuan tulisan ini untuk mendeskripsikan (1) konsep Total Quality Management, (2) landasan teoretis tentang total quality management, dan (3) penerapan Total Quality Management pada Program Studi Manajemen Pendidikan Islam pada Fakultas Tarbiyah dan Keguruan UIN Alauddin Makassar. Terdapat beberapa landasan teori yang mendukung pelaksanaan TQM dalam institusi pendidikan. Salah satunya adalah teori Deming yang dapat diindentifikasi dari (a) model reaksi berantai Deming, (b) siklus perbaikan tanpa akhir Deming, (c) teori Deming tentang Variance, dan (d) empat belas poin manajemen Deming. Penerapan TQM pada Program Studi Manajemen Pendidikan Islam Fakultas Tarbiyah dan Keguruan UIN Alauddin belum maksimal. Terdapat 70,19\% responden mengatakan bahwa penerapan TQM berada pada tingkat biasa-biasa saja, terdapat $0,90 \%$ responden mengatakan baik, dan terdapat $1,85 \%$ responden yang mengatakan penerapan TQM sudah sangat baik.
\end{abstract}

\begin{abstract}
:
The purpose of this paper is to describe (1) the concept of total quality management, (2) the theoretical foundation of total quality management, and (3) the application of total quality management in Education management study program at the Faculty of Education and Teaching Science, UIN Alauddin Makassar. There are some theoretical bases to support the implementation of TQM in educational institutions. One is the theory of Deming which can be identified from (a) Deming's chain reaction model, (b) Deming's continuous improvement cycle, (c) Deming's theory of Variance, and (d) Deming's fourteen points of management. The application of TQM in Management Studies Program Faculty of Tarbiyah and Teaching Education UIN Alauddin have not maximized. The data indicated that $70.19 \%$ respondents said that the implementation of TQM is at a mediocre level, $0.90 \%$ respondents said good, and $1.85 \%$ respondents said that the implementation of TQM has been very good.
\end{abstract}

\section{Kata Kunci:}

Manajemen Pendidikan Islam, Manajemen Mutu, TQM, Perbaikan Mutu Terpadu

SALAH satu permasalahan krusial bangsa ini memasuki abad ke-21 adalah rendahnya mutu pendidikan yang dihasilkan. Rendahnya mutu pendidikan dapat ditelaah baik dari perspektif makro maupun mikro. Secara makro, berdasarkan data dalam Education for All (EFA) Global Monitoring Report 2011 yang dikeluarkan UNESCO menunjukkan bahwa indeks pembangunan pendidikan Indonesia berada pada urutan ke-69 dari 127 negara yang disurvei atau turun empat tingkatan jika dibanding- 
kan hasil survei sebelumnya yang menempatkan Indonesia pada urutan ke 65 . Survei itu menggunakan empat tolok ukur, yaitu angka partisipasi pendidikan dasar, angka melek huruf pada anak usia 15 tahun ke atas, angka partisipasi menurut kesetaraan jender, dan angka bertahan siswa hingga kelas V sekolah dasar. ${ }^{1}$

Secara mikro, rata-rata nilai UN siswa SD pada tahun 2008 hanya mencapai 7,03 dan siswa SMA/SMK/MA mencapai 7,17. Rata-rata nilai UN SMP/MTs adalah sebesar 6,87 dengan tingkat kelulusan sebesar 92,76\%. Rata-rata nilai ujian SMP/MTs tersebut masih di bawah target tahun 2008 yaitu tujuh. Hal ini mengkhawatirkan karena di samping target nasional tidak tercapai, juga tingkat kelulusan masih di bawah 95\%.2 Sekalipun nilai ini telah melampaui target atau standar kelulusan nasional, tetapi nilai tersebut masih terbilang rendah jika dibandingkan dengan nilai kelulusan negara-negara lain. Rendahnya standar kelulusan ini menunjukkan rendahnya kualitas pendidikan yang dihasilkan sebagai wujud dari rendahnya kualitas pengelolaan pendidikan.

Mengamati realitas objektif pengelolaam pendidikan di Indonesia saat ini, Tilaar berpendapat bahwa sebenarnya terdapat delapan permasalahan pendidikan yang perlu mendapat perhatian serius bagi semua kalangan. Kedelapan permasalahan tersebut mencakup kebijakan pendidikan, perkembangan anak Indonesia, kualitas guru, relevansi pendidikan, mutu pendidikan, pemerataan pendidikan, manajemen pendidikan, dan pembiayaan pendidikan. ${ }^{3}$ Menurut Tilaar, sebetulnya permasalahan tersebut sudah lama teridentifikasi yakni sejak sekitar 100 pakar pendidikan dari seluruh Indonesia berkumpul di Cipayung pada tahun 1969 sebagai refleksi dari hasil Penelitian Nasional Pendidikan (PNP) pada tahun 1969. Namun, setelah lebih dari 40 tahun berlalu, perubahan pun tak kunjung terjadi. Bahkan, masyarakat cenderung berpandangan bahwa pencapaian mutu pendidikan tidak dapat terwujud dengan baik selama stigma negatif terhadap pendidikan masih saja mewarnai pemikiran semua pihak. Seperti pemeo yang biasa diperdengarkan "ganti menteri ganti kebijakan". 4

Sejak sistem demokrasi mendapat tempat yang baik di hati masyarakat Indonesia, mulai dari pelaksanaan otonomi daerah, ide percepatan pembangunan, sampai pada keinginan untuk melakukan reformasi pendidikan, politisasi pendidikan begitu marak terjadi. Pendidikan seolah telah di-kebiri dalam suatu ranah politik. Gagasan untuk melaksanakan pendidikan gratis, manajemen berbasis sekolah atau madrasah, pengucuran dana bantuan operasional sekolah (BOS), penguatan kemampuan life skills, dan adanya komite sekolah dan dewan pendidikan semuanya telah direduksi dalam bingkai perpolitikan. Perubahan kebijakan demi kebijakan yang kuat dengan nuansa pendidikan, tetapi sangat kental dengan kandungan politiknya mewarnai pola pengembangan pendidikan di negara ini. Perubahan kebijakan yang dimaksud salah satunya dapat ditelusuri dari perubahan kurikulum, di mana dalam sejarah penyelenggaraan pendidikan di negara kita tercatat sebanyak enam kali perubahan kurikulum pendidikan dasar dan menengah yang berbarengan dengan perubahan strategi pembelajaran. ${ }^{5}$ 
Kurikulum pertama dirancang pada tahun 1968 yang menekankan pada pentingnya pembinaan moral, budi pekerti, agama, kecerdasan dan keterampilan, serta fisik yang kuat dan sehat. Kurikulum 1968 dianggap belum sempurna, kemudian dirancanglah kurikulum 1975. Kurikulum 1975, walaupun telah diarahkan pada pengembangan tiga aspek: kognitif, afektif, dan psikomotor, tetapi belum dapat mewujudkan tujuan pendidikan menurut Undang-Undang Dasar RI 1945. Perubahan pun dilakukan dengan merancang kurikulum 1984 sebagai penyempurnaan kurikulum sebelumnya yang menekankan pada Cara Belajar Siswa Aktif (CBSA). Implementasi kurikulum tahun 1984 dipandang terlalu membebani guru dan murid karena tidak seimbang antara banyaknya materi yang diajarkan dengan ketersediaan waktu, maka dipandang perlu merancang kurikulum 1994 sebagai penyederhanaan kurikulum 1984. Pergantian pengambil kebijakan terus membawa dampak pada perubahan kurikulum yang berimbas pada dirumuskannya Kurikulum Berbasis Kompetensi (KBK) atau disebut kurikulum 2004. Kurikulum ini, kemudian diuji coba hingga pada tahun 2006. Namun, yang terjadi bukan segera menerapkan KBK, tetapi dirumuskan kurikulum baru yang diklaim sebagai penyempurnaan KBK, yakni Kurikulum Tingkat Satuan Pendidikan (KTSP) atau disebut kurikulum 2006. Seiring dengan perubahan perpolitikan yang berimbas pada pergantian kepemimpinan dari berbagai sektor, gagasan untuk menerapkan pendidikan karakter pada tahun 2010, menginspirasi para pengambil kebijakan segera menyempurnakan KTSP untuk mengakomodasi integrasi nilai-nilai karakter dalam pembelajaran.

Berdasarkan pengalaman pada perubahan kurikulum sebelumnya, tampaknya kebijakan pemerintah saat ini cenderung mengarah pada keinginan untuk merancang kurikulum baru dengan klaim untuk menyempurnakan KTSP yang telah berjalan sejak enam tahun yang lalu. Perubahan ini tentu saja dimaksudkan untuk menjawab tantangan terhadap kemerosotan moral, akhlak, dan etika yang kelihatannya menunjukkan kelonggaran, yang artinya, lunturnya nilai-nilai kesopanan yang berlandaskan akhlakul karimah.

Perubahan kebijakan termasuk yang berhubungan dengan pergantian kurikulum, sebenarnya merupakan hal yang wajar dalam menyikapi derasnya arus perubahan global dewasa ini yang menjadi permasalahan adalah perubahan itu tidak diiringi dengan evaluasi mendalam tentang kelemahan dan kelebihan, serta berbagai hasil yang diperoleh dalam penyelenggaran pendidikan, termasuk ketercapaian seluruh target yang telah dirancang sebelumnya. Jika hal ini terjadi, maka pembaharuan dan berbagai bentuk inovasi yang digalakkan tidak dapat berkontribusi secara signifikan dalam perubahan pelaksanaan pendidikan, apalagi jika mengharapkan perbaikan kualitas yang dapat meningkatkan prestasi bangsa ini sejajar dengan negaranegara maju lainnya di dunia umumnya dan di kawasan Asia Pasifik khususnya. Bahkan, kekhawatiran akan terjadi keterpurukan mutu pendidikan pun tidak jarang terjadi di berbagai kalangan jika koreksi total terhadap berbagai kebijakan yang terkesan "buru-buru, setengah hati, dan bersifat reaktif bukan proaktif" tidak disadari oleh para pengambil kebijakan. 
Tanri Abeng dalam setiap kesempatan ketika membawakan acara di Metro TV sering mengatakan; Tidak ada negara yang bangkrut, gagal, atau miskin, yang ada hanyalah negara yang salah kelola. Jika pernyataan ini digeneralisasi dalam ruang lingkup pendidikan, maka dapat dikatakan bahwa "tidak ada istilah keterpurukan mutu pendidikan, yang ada hanyalah pendidikan yang salah kelola". Tanri Abeng kemudian memperkenalkan empat solusi yang terkenal dengan akronim empat (4) K, yakni: komunikasi, koordinasi, kerjasama, dan komitmen. Artinya, untuk memperbaiki kualitas pendidikan, pemerintah, politisi, sekolah, masyarakat, dan seluruh stakeholder hendaknya mempertimbangkan empat aspek tersebut dalam menjalankan tugas dan tanggung jawabnya.

Pertama, komunikasi sering menjadi kendala besar dalam menyatukan visi, tujuan, dan berbagai kendala praktek yang dihadapi di lapangan. Dewan pendidikan, komite sekolah, kepala sekolah, guru-guru, dan masyarakat cenderung bersikap ekslusif dalam menjalankan tugas sehari-hari. Oleh karena itu, penyatuan visi bersama, pandangan, dan sharing pengalaman dengan jalan komunikasi adalah suatu solusi cerdas dalam mengatasi berbagai permasalahan yang dihadapi. Kedua, koordinasi juga menjadi sangat sulit terbangun ketika seluruh komponen dalam pendidikan tidak pernah memahami tanggung jawab masing-masing. Apalagi jika seluruh komponen terkait hanya mampu berjalan sendiri-sendiri sesuai dengan keinginan dan kemampuannya sendiri. Padahal, peluang untuk membagi tugas dan tanggung jawab serta berlomba-lomba untuk menuju pada suatu kebajikan sangat terbuka lebar. Para orang tua memasukkan anak mereka pada suatu sekolah, tentu didasari oleh adanya suatu keyakinan dan apresiasi yang tinggi kepada sekolah tersebut. Dengan demikian, upaya untuk terlibat langsung atau tidak langsung dalam menunjang kemajuan sekolah yang berujung pada peningkatan kualitas peserta didik pada sekolah itu pada hakekatnya merupakan keinginan yang kuat dari para orang tua. Di sinilah pentingnya dewan pendidikan, komite sekolah, dan komponen terkait dalam sekolah tersebut membangun koordinasi yang selaras dengan mempertimbangkan aspek-aspek tugas dan tanggung jawab.

Ketiga, kerjasama antara semua unsur terkait idealnya dapat menyelesaikan permasalahan apa saja yang dihadapi oleh sekolah. Namun, karena keterbatasan para pengambil kebijakan dalam membangun kerjasama tersebut, persoalan sekecil apa saja menjadi sulit terselesaikan. Bahkan, tidak jarang terjadi saling mengklaim diri menjadi yang terbaik dan saling melempar kesalahan merupakan fenomena yang sering terjadi. Para orang tua menyalahkan sekolah karena tidak pernah transparan terutama dalam pengelolaan dana yang melibatkan pihak ketiga, sedangkan kepala sekolah mengklaim diri telah menyumbangkan tenaga dan bahkan dana untuk membangun sekolah yang berkualitas. Begitu pula para guru sering bercerai-berai dalam menjalankan tugas sesuai profesi mereka. Ada yang cenderung cuek dan tidak peduli terhadap apa yang terjadi di sekolah, ada juga yang hanya tahu mengeritik tanpa adanya tawaran solusi, dan bahkan ada juga guru yang berprinsip, "Selamatkan diri dan keluarga masing-masing", serta tidak mau tahu alias tutup mata dengan kejadian di 
sekitar mereka. Oleh karena itu, membangun kerjasama secara kolaboratif dan sinergik perlu dikedepankan dalam rangka membangun sekolah sebagai agen perubahan dalam masyarakat.

Keempat, komitmen bersama dalam memperbaiki kualitas perlu menjadi bagian yang integral yang terintegrasi secara menyeluruh, baik dalam membuat kebijakan maupun dalam pelaksanaan tugas sehari-hari. Komitmen bukan hanya terjadi pada saat pertemuan dan penandatangan kesepakatan saja, melainkan harus berwujud pada kegiatan tindak lanjut disertai upaya monitoring, refleksi, dan evaluasi. Komitmen harus terintegrasi dalam suatu perencanaan, proses pelaksanaan, dan pencapaian hasil.

Mengingat begitu pentingnya membangun mutu secara total dalam suatu negara atau dalam lingkup yang mikro seperti institusi pendidikan, penajaman jalurjalur komunikasi, koordinasi, kerjasama, dan komitmen merupakan komponen yang sangat dibutuhkan dalam suatu manajemen. Namun, untuk memahami secara total tentang kondisi objektif manajemen dari suatu institusi yang hendak dikembangkan tampaknya konsep $4 \mathrm{~K}$ Tanri Abeng seperti disebutkan di atas masih sangat abstrak dan terlalu luas untuk terjemahkan, perlu adanya suatu pemahaman mendalam tentang konsep total quality manajemen, landasan teori total quality management, dan pengukuran atau uji pendidikan mutu itu sendiri paling tidak dalam ruang lingkup pekerjaan kita masing-masing. Jika suatu institusi memahami kondisi kualitas pada masing-masing bidang pekerjaan, maka lambat laun pemahaman komprehensif tentang total quality management dari institusi-institusi yang ada dapat diidentifikasi. Oleh karena itu, tulisan ini berupaya untuk melakukan refleksi kritis terhadap model penerapan total quality management di lingkungan kerja, dalam hal ini pada Program Studi Manajemen Pendidikan Islam Fakultas Tarbiyah dan Keguruan UIN Alauddin Makassar. Adapun yang menjadi fokus pembahasan dalam tulisan ini terdiri atas (1) konsep Total Quality Management, (2) landasan teoritis tentang Total Quality Management, dan (3) model penerapan Total Quality Management di lingkungan kerja. Lingkungan kerja di sini adalah pada Program Studi Manajemen Pendidikan Islam Fakultas Tarbiyah dan Keguruan, di mana penulis bekerja sebagai salah seorang tenaga pendidik di dalamnya.

\section{KONSEP TOTAL QUALITY MANAGEMENT}

Istilah Total Quality Management (TQM) dapat ditelusuri kembali pada awal tahun 1920-an yakni ketika teori statistik pertama kali diterapkan dalam kontrol kualitas produk. Konsep TQM kemudian dikembangkan di Jepang pada tahun 1940-an oleh beberapa sarjana kenamaan dari Amerika Serikat seperti Deming, Juran, dan Feigenbaum. ${ }^{6}$ Pada saat itu, isu-isu seputar kualitas produk berkembang dengan begitu luas menjadi kualitas untuk seluruh aspek dalam suatu organisasi. Di sinilah istilah TQM mulai banyak digunakan. TQP juga dipandang sebagai cara mengelola masa depan yang jauh lebih luas dalam penerapannya dari pada hanya sekedar jaminan produk atau kualitas pelayanan. TQM adalah cara mengelola orang-orang dan 
proses bisnis untuk menjamin kepuasaan pelanggan secara sempurna pada setiap tahap, baik secara internal maupun eksternal.7 Dalam hal ini, TQM dihubungkan dengan sistem kepemimpinan yang efektif.

Lebih jauh dijelaskan bahwa inti dari TQM merupakan hubungan pelanggan pemasok secara internal dan eksternal, dan dalam setiap hubungan didasari oleh proses yang dikelilingi oleh komitmen terhadap kualitas, komunikasi tentang pesanpesan kualitas, mengenal perubahan budaya organisasi untuk menciptakan kualitas total, kemudian ditunjang dengan fungsi utama manajemen orang, proses, dan sistem dalam organisasi. Sistem hubungan inilah yang dimaksudkan dengan total quality management. Artinya, komponen orang, sistem, dan proses sangat didukung oleh bangunan komunikasi, komitmen, dan budaya yang terdapat di dalam organisasi itu sendiri. Komponen-komponen tersebut harus dibangun secara sistimatis dan sistemik. Sistematis artinya bagaimana bagian-bagian yang terdapat dalam manajemen harus secara bertahap dikembangkan dan secara sistemik maksudnya jika terdapat satu bagian yang bermasalah, maka pengaruhnya dapat berdampak bagi tidak berjalannya suatu sistem sebagaimana yang diinginkan. Jika digambarkan hubungan komponen-komponen tersebut, dapat dilihat seperti berikut ini:

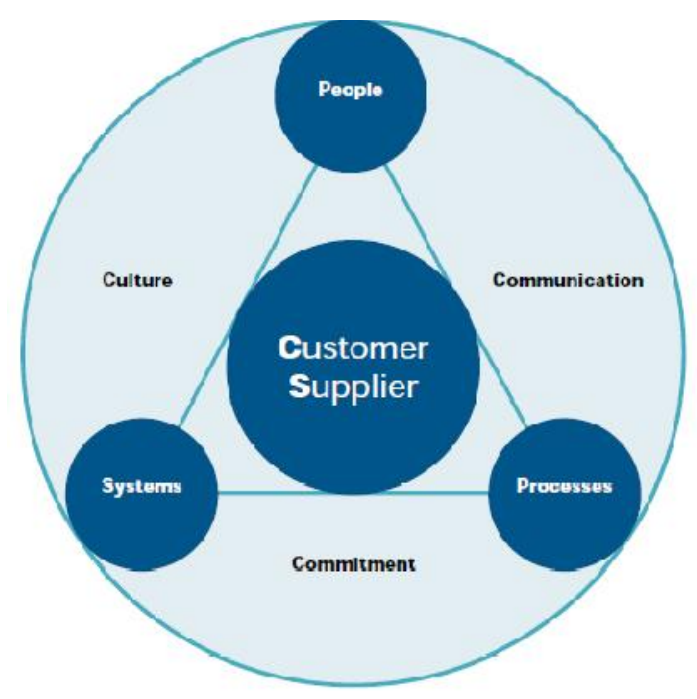

Gambar 1. TQM dalam suatu organisasi ${ }^{8}$

Psychogios and Priporas menjelaskan bahwa "TQM is a total organizational approach for meeting customer needs and expectations that involves all managers and employees in using quantitative methods to improve continuously the organisation's processes, products and services". ${ }^{9}$ Maksudnya, TQM adalah pendekatan organisasi secara terpadu untuk memenuhi kebutuhan dan harapan pelanggan yang mencakup seluruh manajer dan pegawai dalam menggunakan metode kuantitatif guna memperbaiki proses-proses, produk, dan pelayanan organisasi secara terus-menerus.

Dari dua definisi TQM sebagaimana disebutkan di atas, semuanya melihat dari perspektif bisnis, yang artinya definisi tersebut berbicara dalam bingkai dunia usaha. 
Namun, keduanya memandang TQM dari perspektif yang berbeda. Jika definisi pertama cenderung melihat TQM sebagai suatu cara untuk mengelola suatu organisasi, maka definisi kedua memandang TQM sebagai suatu pendekatan organisasi terpadu. Walaupun demikian, elemen penting dari kedua definisi tersebut mencakup hal-hal sebagai berikut:

1. Upaya tanpa henti untuk mencari cara terbaik untuk memperbaiki kualitas;

2. Keterlibatan seluruh pegawai;

3. Kepemimpinan yang bersifat manajerial;

4. Identifikasi budaya kerja; dan

5. Fokus pada pelayanan pelanggan.

Dari perspektif pendidikan, TQM dipandang sebagai "Suatu filosofi tentang perbaikan secara terus menerus, yang dapat memberikan seperangkat alat praktis kepada setiap institusi pendidikan dalam memenuhi kebutuhan, keinginan, dan harapan para pelanggannya, saat ini dan untuk masa yang akan datang". ${ }^{10}$ Seperti dijelaskan sendiri oleh Sallis bahwa definisi tersebut digunakan untuk dua gagasan utama: The first is a philosophy of continuous improvement, the second related meaning uses $T Q M$ to describe the tools and techniques, such as brainstorming. ${ }^{11}$ Dua gagasan yang dimaksud adalah pertama filosofi perbaikan terus menerus, dan kedua untuk mendeskripsikan alat-alat dan teknik-teknik seperti sumbang pendapat. Definisi lain tentang TQM yang lebih spesifik diberikan oleh Babbar dalam dua definisi sebagai berikut:

\section{Definisi Pertama:}

$T Q M$ in a class setting is a philosophy and a set of guiding principles and practices the instructor applies to teaching that represent the foundation for continuous learning and improvement on the part of the students and the instructor. It is the application of procedures related to instruction that improve the quality of education provided to the students and the degree to which the needs of the students and their employers are met, now and in the future. ${ }^{12}$

Definisi tersebut memandang TQM dalam ruang lingkup kelas merupakan suatu filosofi dan seperangkat prinsip dan praktek yang mengarahkan instruktur untuk melaksanakan pembelajaran yang merepresentasi sistem belajar sepanjang hayat dan perbaikan terus-menerus terhadap sesuatu yang berkenaan dengan instruktur dan peserta didik. TQM merupakan aplikasi prosedur yang berkaitan dengan pembelajaran yang dapat memperbaiki kualitas pendidikan yang diberikan kepada siswa dan sejauh mana kebutuhan siswa terpenuhi saat ini dan di masa yang akan datang.

Definisi Kedua:

TQM in a class setting is a process that involves the instructor's adopting a total quality approach to teaching (i.e. attempting to improve the quality of instruction and, in the process, the students' meaningful learning in every possible way) so that the needs of the students and those of their employers are best served. It is the never-ending pursuit of continuous improvement in the quality of education provided to the student. ${ }^{13}$ 
Dalam definisi kedua, TQM dalam ruang lingkup kelas dipandang sebagai proses yang melibatkan instruktur dalam mengadopsi pendekatan kualitas terpadu dari suatu pembelajaran (yakni mencoba memperbaiki kualitas pembelajaran dalam proses, di mana peserta didik dapat belajar dengan bermakna dalam setiap cara yang mungkin diberikan) sehingga kebutuhan peserta didik dan seluruh staf yang ada dapat terlayani dengan baik. TQM merupakan upaya pencarian perbaikan kualitas pendidikan secara terus-menerus yang disediakan untuk pesera didik.

Beberapa elemen penting yang dapat ditelaah dari dua definisi tersebut dapat dijabarkan sebagai berikut:

1. Prinsip dan dan prosedur untuk mengarahkan instruktur (pendidik) dalam pembelajaran;

2. Sistem belajar sepanjang hayat;

3. Perbaikan kualitas pembelajaran secara terus menerus;

4. Upaya pemenuhan kebutuhan peserta didik;

5. Keterlibatan seluruh pendidik, peserta didik, dan tenaga kependidikan;

6. Perbaikan pelayanan pembelajaran; dan

7. Perbaikan proses.

\section{LANDASAN TEORITIS TOTAL QUALITY MANAGEMENT}

Sebelum lebih jauh menjelaskan teori-teori yang mendasari TQM, terlebih dahulu dijelaskan tentang teori. Snelbecker menyatakan bahwa sedikitnya ada empat macam definisi yang dapat dibedakan mulai dari yang sangat umum sampai pada yang sangat terbatas. Secara umum dikatakan bahwa teori adalah segala aspek ilmu yang tidak semata-mata bersifat empirik, dan yang sangat khusus adalah ringkasan pernyataan yang melukiskan dan menata sejumlah pengamatan empirik. ${ }^{14}$

Banyak sekali teori yang mendasari kajian TQM. Teori-teori yang umum dijadikan referensi dalam menganalisis manajemen kualitas terpadu adalah teori Deming, teori Crosby, dan teori Juran. Namun, dalam makalah ini hanya menjelaskan teori Deming dengan pertimbangan bahwa teori ini sangat sesuai untuk menjadi landasan atau pijakan dasar dalam mengkaji manajemen kualitas lembaga pendidikan dalam lingkungan tempat penulis bekerja, yakni pada Program Studi Manajemen Pendidikan Islam Fakultas Tarbiyah dan Keguruan UIN Alauddin Makasar.

Edward Deming memandang bahwa kualitas manajemen diperlukan dalam suatu kegiatan organisasi yang luas bukan tugas-tugas teknis dari suatu pimpinan atau kelompok jaminan kualitas. Dia mengidentifikasi kualitas sebagai tanggung jawab manajemen, mengamati bahwa pimpinan harus menciptakan sistem dan proses yang menghasilkan kualitas. Produk yang berkualitas menggabungkan perencanaan yang baik dengan metode produksi yang efektif yakni produksi yang memenuhi kondisi suatu organisasi dalam menjamin kualitas. ${ }^{15}$

\section{Model Reaksi Berantai Deming}

Deming menekankan bahwa manajemen puncak memiliki tanggung jawab yang lebih tinggi dalam perbaikan kualitas daripada manajemen tingkat senior atau 
menengah. Deming menganjurkan untuk menggunakan siklus yang tidak pernah berakhir, desain produk, manufaktur, pengujian, dan penjualan diikuti dengan melakukan survei pasar dan kemudian mendesain ulang dan sebagainya. Dia mengatakan bahwa kualitas yang lebih baik dapat mengarahkan produktivitas yang lebih tinggi, yang pada gilirannya dapat membangun kekuatan kompetitif jangka panjang. Hal ini disebut Deming sebagai Chain Reaction Theory (teori reaksi berantai). Teori ini mengatakan bahwa perbaikan kualitas dapat menurunkan biaya karena dapat menyebabkan pekerjaan tidak dilakukan atau diulang kembali, membawa sedikit kesalahan, keterlambatan dan penundaan, dan kualitas lebih baik, sementara harga lebih rendah, perusahaan dapat menjangkau pasar yang lebih besar, membagi bidang usaha, dan menyediakan peluang kerja yang semakin banyak. ${ }^{16}$

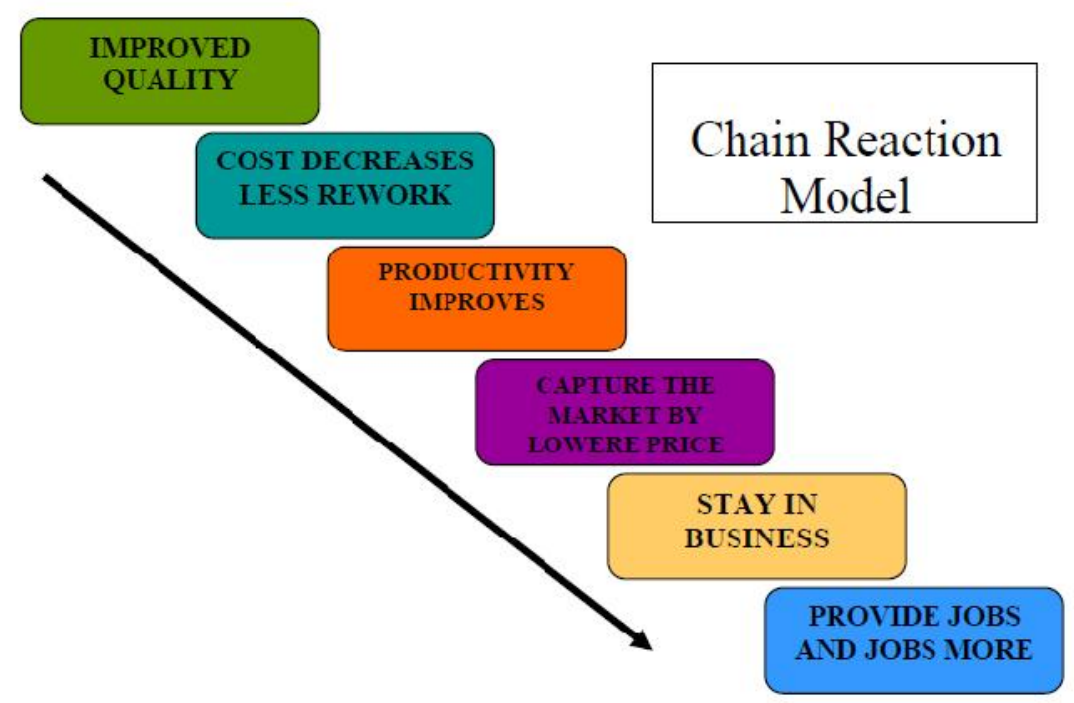

Gambar 2. Model Reaksi Berantai ${ }^{17}$

\section{Siklus Perbaikan Tanpa Akhir Deming}

Sedangkan yang dimaksudkan oleh Deming dengan Never ending improvement cycle (siklus perbaikan tanpa akhir) atau lebih dikenal dengan PDCA-Cycle adalah suatu siklus yang digunakan untuk menyelesaikan masalah secara terus-menerus tanpa henti melalui proses siklus yang dilakukan secara berulang sampai kondisi perbaikan dapat mencapai hasil yang lebih baik. Siklus PDCA itu adalah akronim dari:

$\mathrm{P}=$ Plan (perencanaan)

$\mathrm{D}=\mathrm{Do}$ (melakukan, mengerjakan)

$\mathrm{C}=$ Check (mengecek, memeriksa)

$\mathrm{A}=$ Act (berbuat, bertindak). ${ }^{18}$

Adapun siklus perbaikan tanpa akhir sebagaimana disebutkan di atas dapat digambarkan dalam lingkaran siklus sebagai berikut: 


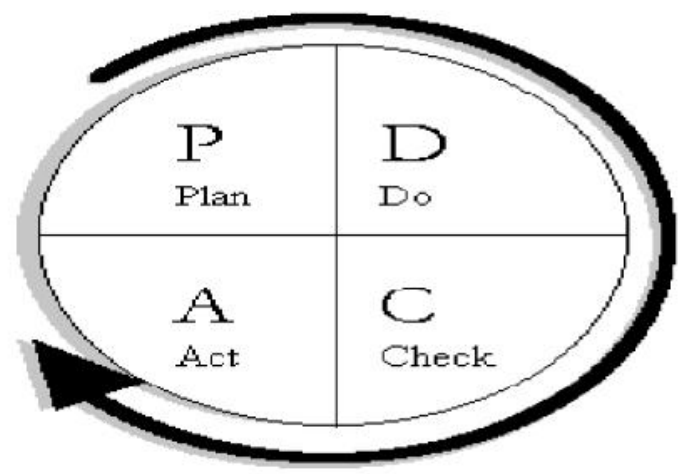

Gambar 3. Siklus l’erba1kan Ianpa Akhir'1y

Berdasarkan gambar tersebut, langkah pertama yang harus dilakukan dalam memperbaiki kualitas adalah perencanaan (plan). Dalam melakukan perencaan, tim atau kelompok yang hendak memperbaiki kualitas terpadu perlu melakukan analisis kebutuhan dengan mengukur kondisi objektif manajemen. Perlu juga memilih proses yang membutuhkan perbaikan, membuat dokumentasi terhadap proses yang telah dipilih, kemudian merumuskan tujuan yang hendak dicapai. Setelah mengukur kebutuhan dan biaya yang mungkin dikeluarkan, tim itu mengembangkan perencanaan dengan menggunakan standar perbaikan yang terukur.

Langkah selanjutnya adalah melakukan (do) semua yang telah direncanakan. Pada saat melakukan perencanaan, perlu dibarengi dengan pengawasan terhadap kemajuan perbaikan. Dengan demikian, data perlu dikumpulkan secara terus-menerus untuk mengukur perbaikan proses. Setelah itu, perlu dilakukan pengecekan (check) dengan menganalisis data yang telah dikumpulkan sebelumnya. Kemudian, dilanjutkan dengan menemukan hasil sejauhmana pencapaian hasil mendekati tujuan yang telah diremuskan pada bagian perencanaan. Langkah terakhir dalam proses perbaikan mutu adalah memberikan tindakan (act) dengan melakukan perbaikan atau merevisi proses untuk mencapai standar atau target yang diinginkan.

Berdasarkan uraian tersebut di atas maka dapat dijelaskan bahwa Siklus Perbaikan Tanpa Akhir Deming dapat disimpulkan sebagai berikut:

Plan

1. Menganalisis kebutuhan

2. Membuat dokumentasi

3. Merumuskan tujuan

4. Mengembangkan perencanaan

Do

1. Mengawasi kemajuan

2. Mengumpulkan data secara terus menerus

3. Mengukur perbaikan proses

Check

1. Menganalisis data yang dikumpulkan

2. Menentukan kondisi kemajuan 
Act

1. Mengukur pencapaian dengan menggunakan standar yang jelas

2. Menentukan kondisi yang perlu diperbaiki

3. Merevisi atau melakukan perbaikan proses.

\section{Teori Deming tentang Variance}

Deming membuat kategori perubahan melalui dua tahap; perubahan yang dapat dikontrol dan perubahan yang tidak terkontrol. Yang dimaksud dengan perubahan yang dapat dikontrol adalah perubahan yang terjadi dari proses standar yang pekerja dapat mengontrolnya dengan menggunakan alat-alat kontrol apa saja. Sedangkan perubahan yang tidak terkontrol adalah perubahan dari proses standar yang tidak dapat diawasi disebabkan oleh pengaruh beberapa faktor. Menurut Deming, perubahan dapat diperbaiki atau dikoreksi oleh pegawai atau manajer dengan mengubah penyebab umum atau menghapus atau melepas penyebab-penyebab yang khusus. Dalam mengubah penyebab-penyebab yang umum memerlukan proses pelaksanaan dalam waktu yang relatif lama (long term operating proces) untuk mengkaji kelemahan dalam mendesain produk, perlengkapan, kegagalan atau kerusakan yang terjadi, atau mungkin kekurangan biaya dalam pemeliharaan. ${ }^{20}$ Sedangkan jika melepas penyebab-penyebab khusus yang terjadi dapat dilakukan dalam waktu yang pendek dengan pertimbangan adanya keterbatasan pengetahuan atau karena kelalaian pekerja. Untuk lebih memahami lebih jauh tentang proses perubahan yang terjadi, maka dapat digambarkan sebagai berikut:

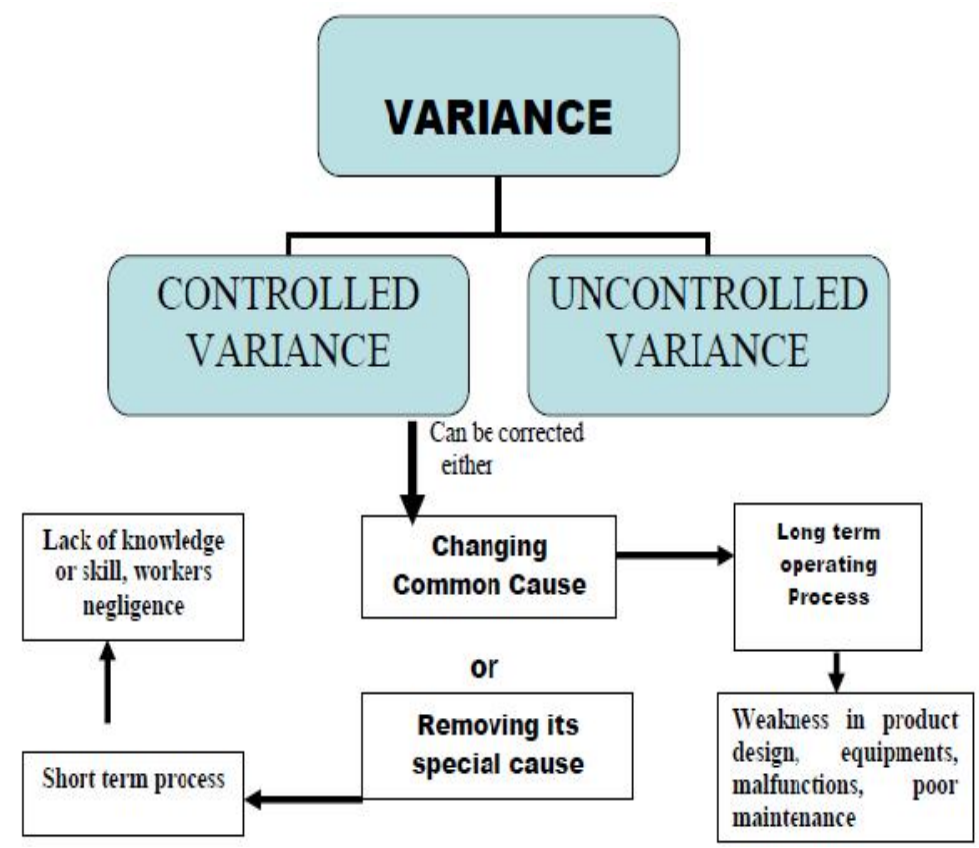

Gambar 4. Model Perubahan Perbaikan²1 


\section{Empat Belas Poin Manajemen Deming}

Disraeli, Sallis, dan Gomes membuat ringkasan tentang 14 poin manajemen Deming sebagaimana dijabarkan sebagai berikut:

1. Ciptakan keajegan tujuan untuk perbaikan pelayanan dan produk;

2. Adopsi filosopi baru;

3. Hentikan ketergantungan pada inspeksi masa untuk mencapai mutu;

4. Akhiri praktik pemberian bisnis pada label harga saja;

5. Perbaiki sistem produksi dan jasa secara terus-menerus dan selamanya;

6. Lembagakan metode-metode pelatihan kerja modern;

7. Lembagakan metode-metode pengawasan dan kepemimpinan modern;

8. Hilangkan rasa takut agar setiap orang dapat bekerja secara efektif;

9. Buka berbagai kendala antara departemen;

10. Hapuskan slogan, poster, dan desakan serta tingkatkan produktivitas tanpa menambah beban kerja;

11. Hapuskan standar kerja dan bagian angka-angka;

12. Hilangkan kendala-kendala yang merampas kebanggaan karyawan atas keahlian;

13. Lembagakan program pendidikan dan pelatihan yang menyemangatkan setiap karyawan; dan

14. Terjemahkan komitmen manajemen puncak untuk memperbaiki kualitas dan produksi. 22

Walaupun empat belas poin tersebut tampaknya lebih cenderung diterapkan pada manajemen dunia usaha, namun bukan berarti tidak dapat diterapkan dalam manajemen institusi pendidikan. Semua komponen yang ada dapat diimplementasikan dalam berbagai manajemen kualitas terpadu termasuk dalam ruang lingkup kerja yang lebih kecil seperti pengelolaan kelas pada setiap kali pelaksanaan pembelajaran.

\section{PENERAPAN TQM DI LINGKUNGAN KERJA}

Sebelum menguraikan bagaimana pelaksanaan TQM di lingkungan kerja, dalam hal ini pada Program Studi Manajemen Pendidikan Islam di Fakultas Tarbiyah dan Keguruan UIN Alauddin Makassar, terlebih dahulu dijelaskan bahwa berdasarkan hasil observasi singkat yang dilakukan penulis dalam mengkaji model kepemimpinan yang diterapkan di lingkungan Fakultas Tarbiyah menunjukkan bahwa lembaga ini menjalankan pendekatan kepemimpinan dari atas ke bawah (top-down) dalam setiap pengambilan kebijakan, bukan pendekatan dari bawah ke atas (bottom-up). Hal ini dapat dilihat dari akumulasi kebijakan yang hanya melibatkan tataran manajemen puncak dalam setiap kali melahirkan suatu kebijakan baru. Sering kedengaran istilah yang dalam perspektif manajemen modern agak ganjil seperti RAPIM (rapat pimpinan) yang hanya melibatkan sekelompok kecil unsur pimpinan yang dilakukan hampir setiap saat. Hal inilah yang diklaim oleh sebagian top manajemen sebagai kepemimpinan yang bersifat bottom up karena melibatkan para pimpinan pada level setingkat lebih di bawah. Misalnya Rektor mengundang para dekan dan kepala-kepala biro, atau kalau pada tataran fakultas, dekan memanggil para ketua jurusan dan 
program studi. Kepemimpinan semacam ini oleh sebagian yang lain mengklaimnya sebagai kepemimpinan kolektif karena dianggap semua unsur pimpinan telah dilibatkan.

Kepemimpinan yang hanya mengandalkan keterlibatan sebagian kecil unsur pimpinan dan memberikan instruksi dari atas, bukan saja bersifat menerapkan suatu kepemimpinan yang tidak demokratis dan otokratik-individualistik, melainkan telah mengabaikan pandangan-pandangan cemerlang dari para dosen dan karyawan yang notabene berlatar belakang pendidikan tinggi yang perlu diapresiasi pemikiran dan hasil pengalamannya. Seandainya bawahan memiliki latar belakang yang minim dan pendidikan yang tidak memadai untuk dilibatkan dalam suatu kepemimpinan termasuk dalam memutuskan suatu kebijakan, pelaksanaan kepemimpinan top-down masih dianggap wajar. Hal ini pun sering tidak lagi relevan dengan perkembangan dewasa ini, di mana setiap orang dapat mengakses informasi dan ilmu pengetahuan dari berbagai sumber yang tersedia.

Tampaknya dalam menganalisis model penerapan TQM dalam Lingkup Program Studi Manajemen Pendidikan Islam Fakultas Tarbiyah dan Keguruan ini tidak dapat digunakan seluruh komponen dalam teori Deming di atas mengingat keterbatasan waktu dan dana yang digunakan. Penulis hanya menggunakan model Siklus Perbaikan Tanpa Akhir Deming atau oleh Deming sendiri menyebutnya sebagai never ending improvement cycle. Untuk lebih terarah dan terincinya pembahasan mengeni kondisi TQM dalam lingkungan kerja, perlu diuraikan satu demi satu berdasarkan komponen-komponen yang telah diberikan Deming, yakni perencanaan (plan), melakukan, mengerjakan (do), mengecek, memeriksa (check), berbuat, bertindak (act).

\section{Perencanaan}

Hal yang paling mendasar tentang TQM dalam suatu organisasi adalah membuat perencanaan perbaikan. Dalam membuat perencanaan, perlu menganalisis kebutuhan, membuat dokumentasi, merumuskan tujuan yang hendak dicapai, dan mengembangkan perencanaan dengan menggunakan standar perbaikan yang terukur. Adapun hasil pengukuran dilakukan dapat dilihat dari tabel berikut ini.

Tabel 1. Perencanaan Perbaikan

\begin{tabular}{|c|c|c|c|c|c|}
\hline KOMPONEN YANG DIUKUR & 1 & 2 & 3 & 4 & 5 \\
\hline Perencanaan: & & & & & \\
\hline 1. Menganalisis Kebutuhan & & & 6 & 2 & 2 \\
\cline { 2 - 6 } 2. Membuat dokumentasi & & & 8 & & 2 \\
\hline 3. Merumuskan Tujuan & & & 5 & 3 & 2 \\
\hline 4. Mengembangkan Perencanaan & & & 8 & & 2 \\
\hline
\end{tabular}

Berdasarkan tabel 1 di atas, perencanaan perbaikan menunjukkan bahwa terdapat $6(60 \%)$ responden menganalisis kebutuhan biasa-biasa saja (tidak terlalu jelek 
dan tidak terlalu baik), $2(20 \%)$ responden mengatakan baik, dan terdapat $2(20 \%)$ responden mengatakan baik sekali. Dalam membuat dokumentasi, terdapat $8(80 \%)$ responden mengatakan biasa-biasa saja dan hanya $2(20 \%)$ responden yang mengatakan baik sekali. Dalam merumuskan tujuan, terdapat $5(50 \%)$ mengatakan biasabiasa saja, $3(30 \%)$ responden menjawab baik, dan terdapat $2(20 \%)$ responden mengatakan baik sekali. Kemudian, dalam mengembangkan perencanaan, terdapat 8 $(80 \%)$ responden menjawab biasa-biasa saja, dan hanya $2(20 \%)$ responden mengatakan baik sekali.

\section{Perlakuan (Pelaksanaan Perencanaan)}

Dari semua rencana yang disusun, perlu dibarengi dengan pelaksanaan langsung di lapangan dengan memperhatikan berbagai aspek yang mengitarinya. Untuk melaksanakan berbagai perencanaan komponen-komponen yang diukur adalah mengawasi kemajuan, mengumpulkan data secara terus-menerus, dan mengukur perbaikan proses. Adapun pelaksanaan perencanaan TQM, dapat digambarkan melalui tabel sebagai berikut:

Tabel 2. Pelaksanaan Perencanaan

\begin{tabular}{|c|c|c|c|c|c|}
\hline KOMPONEN YANG DIUKUR & 1 & 2 & 3 & 4 & 5 \\
\hline Perlakuan: & & & & & \\
\hline 1. Mengawasi kemajuan & & & 7 & 1 & 2 \\
$\begin{array}{l}\text { Mengumpulkan data secara terus } \\
\text { menerus }\end{array}$ & & & 6 & 2 & 1 \\
\cline { 2 - 6 } 3. Mengukur perbaikan proses & & & 8 & & 2 \\
\hline
\end{tabular}

Berdasarkan tabel 2 tersebut dapat disimpulkan bahwa terdapat 7 (70\%) responden yang mengatakan bahwa mengawasi kemajuan masih berada pada tingkat biasa-biasa saja, $1(10 \%)$ responden mengatakan baik, dan terdapat $2(20 \%)$ mengatakan baik sekali. Berkaitan dengan kegiatan mengumpulkan data secara terus-menerus, terdapat $6(60 \%)$ responden mengatakan biasa-biasa saja, terdapat $2(20 \%)$ menjawab baik, dan terdapat $1(10 \%)$ responden menjawab sudah baik sekali. Sedangkan kegiatan untuk mengukur perbaikan proses terapat $8(80 \%)$ responden menjawab biasa-biasa saja dan terdapat $2(20 \%)$ responden yang menjawab baik sekali.

\section{Pengecekan}

Setelah membuat perencanaan dan melaksanakan semua rencana yang telah dirancang, perlu dilanjutkan dengan pengecekan agar dapat mengetahui sejauhmana tujuan yang telah dibuat dapat direalisasikan. Semakin sering melakukan pengecekan, semakin banyak pengetahuan yang diperoleh tentang proses perkembangan, kemajuan, atau perbaikan yang terdapat dalam organisasi. Dalam melakukan pengecekan, terdapat dua komponen yang dipandang sangat penting untuk dilibatkan: pertama, menganalisis data yang dikumpulkan, dan kedua, menentukan kondisi kemajuan yang telah dicapai. Adapun proses pengecekan yang dilakukan dalam lingkungan kerja dapat dilihat dalam tabel 3 berikut. 
Tabel 3. Pengecekan Kemajuan Manajemen

\begin{tabular}{|l|l|l|l|l|l|}
\hline \multicolumn{1}{|c|}{ KOMPONEN YANG DIUKUR } & 1 & 2 & 3 & 4 & 5 \\
\hline Pengecekan: & & & & & \\
\hline $\begin{array}{l}\text { 1. Menganalisis data yang dikumpulkan } \\
\text { 2. Menentukan kondisi kemajuan }\end{array}$ & & & 8 & & 2 \\
\cline { 2 - 7 } & & & 8 & & 2 \\
\hline
\end{tabular}

Tabel 3 di atas memperlihatkan bahwa terdapat $8(80 \%)$ responden mengatakan biasa-biasa saja dalam melakukan kegiatan menganalisis data yang dikumpulkan dan hanya terdapat 2 (20\%) yang menjawab baik sekali. Begitu pula dengan kegiatan pengecekan dalam kaitan dengan menentukan kemajuan, terdapat $8(80 \%)$ responden menjawab biasa-biasa saja dan hanya $2(20 \%)$ responden yang mengatakan baik sekali.

\section{Melakukan Tindakan}

Merespon seluruh hasil perencanaan, pelaksanaan, dan pengecekan tentu membutuhkan kejelian tersendiri untuk mendapatkan suatu perbaikan kualitas secara terus-menerus atau memberikan tindakan yang sesuai. Kesalahan dalam memberikan tindakan dapat menyebabkan kefatalan dalam mengembangkan suatu produktivitas organisasi. Oeh karena itu, tindakan yang dapat diberikan mencakup mengukur pencapaian kualitas dengan menggunakan standar yang terukur baik dilihat dari segi reliabilitas dan validitasnya. Selain itu, perlu menentukan kondisi kualitas yang perlu diperbaiki dan merevisi berbagai kelemahan yang mungkin diperoleh. Adapun gambar umum tentang penerapan tindakan dalam TQM pada Program Studi Manajemen Pendidikan Islam dapat dijabarkan dalam tabel sebagai berikut:

Tabel 4. Pemberian Tindakan Perbaikan

\begin{tabular}{|c|c|c|c|c|c|}
\hline & 1 & 2 & 3 & 4 & 5 \\
\hline \multicolumn{6}{|l|}{ Tindakan } \\
\hline \multirow{3}{*}{$\begin{array}{l}\text { 1. Mengukur pencapaian dengan } \\
\text { menggunakan standar yang jelas } \\
\text { 2. Menentukan kondisi yang perlu } \\
\text { diperbaiki } \\
\text { 3. Merevisi atau melakukan perbaikan } \\
\text { proses }\end{array}$} & & & 8 & & 2 \\
\hline & & & 6 & 3 & 1 \\
\hline & & & 7 & 1 & 2 \\
\hline
\end{tabular}

Dari data yang terlihat pada tabel 4 tersebut dapat dijelaskan bahwa aktivitas mengukur pencapaian target berdasarkan tujuan yang direncanakan dengan menggunakan standar yang jelas menunjukkan bahwa terdapat $8(80 \%)$ responden menjawab biasa-biasa saja dan hanya $2(20 \%)$ responden saja yang menjawab baik sekali. Dalam hubungannya dengan pemberian tindakan untuk menentukan kondisi yang perlu diperbaiki, terdapat $6(60 \%)$ responden mengatakan biasa-biasa saja, terdapat 3 $(30 \%)$ yang menjawab baik, dan $1(10 \%)$ lainnya mengatakan sangat baik. Yang 
terakhir berhubungan dengan merevisi atau melakukan perbaikan proses menunjukkan terdapat 7 (70\%) responden menjawab biasa-biasa saja, terdapat $1(10 \%)$ responden mengatakan sedang-sedang saja, dan $2(20 \%)$ menjawab sudah menunjukkan hasil yang sangat baik.

Jadi, jika dihitung secara keseluruhan mulai dari perencanaan, pelaksanaan, pengecekan sampai dengan pemberian tindakan, maka dapat dikatakan bahwa penerapan TQM pada Program Studi Manajemen Pendidikan Fakultas Tarbiyah dan Keguruan UIN Alauddin belum mengadopsi sistem kepemimpinan modern dengan menggunakan manajemen mutu atau kualitas terpadu. Terbukti dari data hasil survei yang dilakukan menunjukan bahwa 70,19\% masih biasa-biasa saja, 0,90\% baik, dan hanya $1,85 \%$ menunjukkan hasil yang sangat baik. Sedangkan yang lainnya untuk tingkat jelek dan jelek sekali adalah 0 persen yang berarti pelaksanaan TQM menunjukkan hasil yang dominan pada tingkat biasa-biasa saja. Jika digambarkan lebih rinci, maka penerapan TQM di lingkungan kerja penulis dapat dijabarkan sebagai berikut:

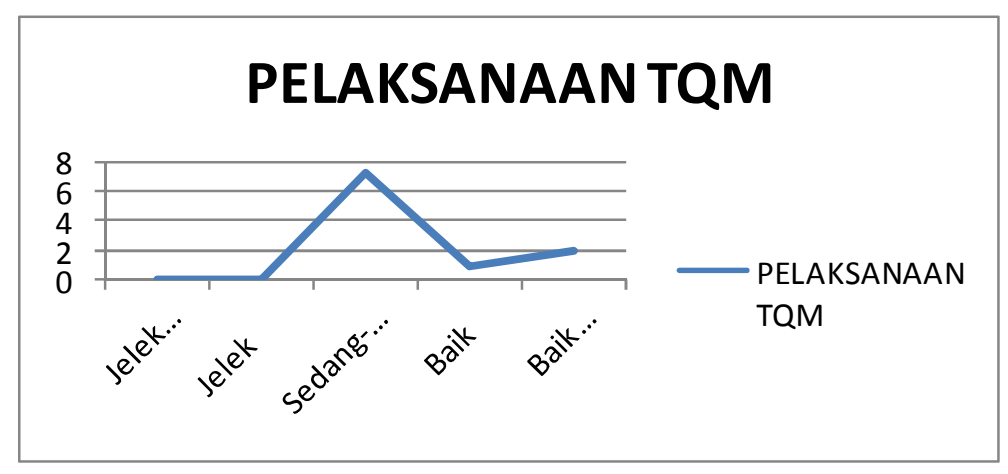

Tingginya angka biasa-biasa saja dalam penerapan TQM pada Program Studi Manajemen Pendidikan Islam Fakultas Tarbiyah dan Keguruan menunjukkan bahwa pola majemen yang dilakukan masih mengadopsi manajemen tradisional, belum mengadaptasi model kepemimpinan modern. Hal ini menunjukkan perlunya dilakukan pengembangan TQM dengan melibatkan seluruh komponen yang terdapat dalam Program Studi Manajemen Pendidikan Islam.

Tampaknya kegiatan rutinitas seperti mengajar, membimbing, memeriksa skripsi, dan memberikan tanda tangan sangat mendominasi aktivitas keseharian program studi. Sedangkan, membuat target penerimaan mahasiswa baru, menganalisis rasio input dan output, serta studi mendalam terhadap berbagai hambatan yang ada amat sangat jarang dilakukan. Hal inilah memberikan indikasi kepada menulis untuk menjustifikasi bahwa sistem kepemimpinan mereka masih mengadopsi model kepemimpinan tradisional yang segalanya hanya ditentukan dan dilakukan atas dasar inisiatif dari atasan. Walaupun demikian, Program Studi Manajemen Pendidikan Islam pada Fakultas Tarbiyah dan Keguruan UIN Alauddin Makassar menunjukkan hasil yang memiliki potensi besar untuk dikembangkan. 


\section{SIMPULAN}

Berdasarkan hasil survei yang dilakukan tentang penerapan TQM di lingkungan kerja, yakni pada Program Studi Manajemen Pendidikan Islam Fakultas Tarbiyah dan Keguruan UIN Alauddin Makassar dapat disimpulkan sebagai berikut:

1. Ketika berbicara mengenai Manajemen Kualitas Terpadu atau TQM, maka konsepnya dapat ditelaah melalui elemen-elemen penting seperti (a) prinsip dan dan prosedur untuk mengarahkan instruktur (pendidik) dalam pembelajaran, (b) sistem belajar sepanjang hayat, (c) perbaikan kualitas pembelajaran secara terus menerus, (d) upaya pemenuhan kebutuhan peserta didik, (e) keterlibatan seluruh pendidik, peserta didik, dan tenaga kependidikan, (f) perbaikan pelayanan pembelajaran, dan $(\mathrm{g})$ perbaikan proses.

2. Terdapat beberapa landasan teori yang mendukung pelaksanaan TQM dalam institusi pendidikan. Salah satunya adalah teori Deming yang dapat diindentifikasi dari (a) model reaksi berantai Deming, (b) siklus perbaikan tanpa akhir Deming, (c) teori Deming tentang Variance, dan (d) empat belas poin manajemen Deming.

3. Penerapan TQM di Lingkungan Kerja menunjukkan bahwa Program Studi Manajemen Pendidikan Fakultas Tarbiyah dan Keguruan UIN Alauddin belum mengadopsi seluruhnya sistem kepemimpinan modern dengan menggunakan manajemen mutu atau kualitas terpadu. Hal ini dapat ditunjukkan dengaan data terdapat $70,19 \%$ responden mengatakan penerapan TQM berada pada tingkat biasa-biasa saja, terdapat $0,90 \%$ responden mengatakan baik, dan terdapat 1,85\% responden yang mengatakan penerapan TQM sudah sangat baik.

\section{CATATAN AKHIR:}

1. Ki Supriyoko, Kinerja Guru (http://isroeddeh.blogspot.com/2010/07/kinerja-guru.html). 2011, h. 1.

2. Departemen Pendidikan Nasional, Rencana Strategis Departemen Pendidikan Nasional Tahun 2010-2014, 2009, h. $28-29$.

3. Tilaar dalam Atmajaya, Permasalahan Pendidikan Indonesia Perlu Dipetakan Kembali, http:/ / www.atmajaya.ac.id/content.asp?f=0\&id=690, 2012, h. 1.

4. Ibid.,

5. Muhammad Yaumi, KBK: antara Harapan dan Kenyataan. Pendidikan Network Online; http:/ / researchengines.com/1205yaumi.html (Diakses tanggal 17 April, 2012), h. 1-2

6. BPIR. History of Quality. Online; http://www.bpir.com/total-quality-management-history-of-tqm-and-business-excellence-bpir.com.html (diakses 18 April, 2012)

7. Department of Trade and Industry. Total Quality Management (TQM). Online http://www.businessballs.com/dtiresources/total_quality_management_TQM.pdf (Diakses Tanggal 19 April, 2012), h. 1-5.

8. Ibid., h. 1.

9. Alexandos G. Psychogios dan Vasilios Priporas. Understanding Total Quality Management in Context Qualitative Research on Managers' Awareness of TQM Aspects in the Greek Service Industry. The Quality Report, Volume 12 Number 1 March 2007, h. 40-66.

10. Edward Sallis, Total Quality Management in Education, Manajemen Mutu Pendidikan. Versi Terjemahan Oleh Riyadi, Ahmad Ali dan Fahrurrozi. Jogjakarta: Ircisod. 2008, h. 73. 
11. Edward Sallis, Total Quality Management in Education. Sterling VA: Stylus Publishing Inc. 2002, h. 25

12. Sunil Babbar, Applying total quality management to educational instruction: A case study from a US public university. International Journal of Public Sector Management, Vol. 8 No. 7, 1995, pp. 35-55, h. 38

13. Sunil Babbar, Ibid, h. 38

14. Glenn E. Snelbecker, Learning Theory, Instructional Theory, and Psychoeducational Design. New York: McGraw-Hill Book Campany. 1974, h. 31-32)

15. Edward Deming, A System of Profound Knowledge. Washington DC: Pearson 1990, h. 22.

16. Shyamal Gomes, Quality Management Philosophies. Online; http://xisspm.files.wordpress.com/2011/07/chap2-quality-management-philosophy.-pdf (Diakses Tanggal 19 April, 2012), h. 2.

17. Ibid., h. 2.

18. Ibid., h. 5 .

19. Ibid., h. 5.

20. Rungtusanatham dkk. 1998 dkk. A replication study of a theory of quality management underlying the Deming management method: insights from an Italian context. Journal of Operations Management, Volume 17, Issue 1, December 1998, Pages 77-95.

21. Ibid.,

22. Benjamin Disraeli, Deming's 14 Points forManagement. Online; http://www.stat.auckland.ac.nz/ mullins/quality/Deming.pdf (Diakses Tanggal 20 April, 2012), Edward Sallis, Total Quality Management in Education. Sterling VA: Stylus Publishing Inc. 2002, dan Shyamal Gomes, Quality Management Philosophies. Online; http://xisspm.files.wordpress.com/2011/07/chap2-quality-management-philosophy.pdf (Diakses Tanggal 19 April, 2012).

\section{DAFTAR PUSTAKA:}

Atmajaya. Permasalahan Pendidikan Indonesia Perlu Dipetakan Kembali. Online; http:/ / www.atmajaya.ac.id/content.asp?f=0\&id=690 (diakses tanggal 17 April, 2012).

Babbar, Sunil. Applying total quality management to educational instruction: A case study from a US public university. International Journal of Public Sector Management, Vol. 8 No. 7, 1995, pp. 35-55.

BPIR. History of Quality. Online; http://www.bpir.com/total-quality-management-historyof-tqm-and-business-excellence-bpir.com.html (diakses 18 April, 2012)

Department of Trade and Industry. Total Quality Management (TQM). Online-http://www.businessballs.com/dtiresources/total_quality_management_TQM.pdf (Diakses Tanggal 19 April, 2012).

Deming, Edward. A System of Profound Knowledge. Washington DC: Pearson 1990, h. 22.

Disraeli, Benjamin. Deming's 14 Points forManagement. Online; http://www.stat.auckland.ac.nz/ mullins/quality/Deming.pdf (Diakses Tanggal 20 April, 2012).

Gomes, Shyamal. Quality Management Philosophies. Online; http://xisspm.files.wordpress.com/2011/07/chap2-quality-management-philosophy.pdf (Diakses Tanggal 19 April, 2012).

Levine, Ronda. Theories in Total Quality Management. Online; http://www.brighthub.com/office/project-management/articles/72443.aspx (Diakses,Tanggal 19 April, 2012).

Rungtusanatham dkk. 1998 dkk. A replication study of a theory of quality management underlying the Deming management method: insights from an Italian context. Journal of 
Operations Management, Volume 17, Issue 1, December 1998, Pages 77-95.

Sallis, Edward. Total Quality Management in Education, Manajemen Mutu Pendidikan. Versi Terjemahan Oleh Riyadi, Ahmad Ali dan Fahrurrozi. Jogjakarta: Ircisod. 2008.

Sallis, Edward. Total Quality Management in Education. Sterling VA: Stylus Publishing Inc. 2002.

Snelbecker, Glenn E. Learning Theory, Instructional Theory, and Psychoeducational Design. New York: McGraw-Hill Book Campany. 1974.

Yaumi, Muhammad. KBK: antara Harapan dan Kenyataan. Pendidikan Network Online; http:/ / researchengines.com/1205yaumi.html (Diakses tanggal 17 April, 2012). 